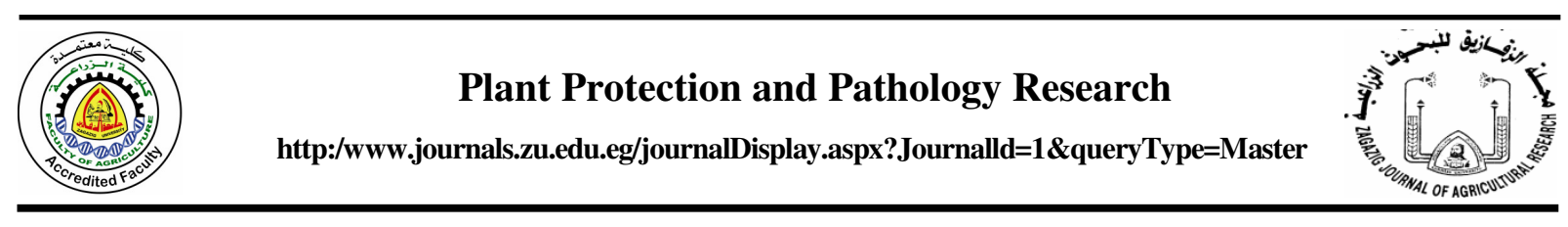

\title{
STUDIES ON FUNGI ASSOCIATED WITH PEA SEEDS AND THEIR EFFECT ON GERMINATION AND SOME SEED CHARACTERS
}

\author{
Mahmoud A.A. Youssef ${ }^{2 *}$, A.Z. Aly ${ }^{1}$, M.R.A. Tohamy ${ }^{1}$ and M. I. Ghonim ${ }^{2}$ \\ 1. Plant Pathol. Dept., Fac. Agric., Zagazig Univ., Egypt \\ 2. Seed Pathol. Res. Dept., Plant Pathol. Res. Inst., ARC, Giza, Egypt
}

Received: 07/03/2018 ; Accepted: 13/05/2018

\begin{abstract}
Seed borne fungi of 45 pea seed samples of Master-B cultivar were examined. These samples were collected from main production area of Egypt. A total number of 28 species, representing 19 genera of fungi was isolated and identified from pea seeds. The agar plate method was more accurate for detection of the most associated seed borne fungi compared with blotter method. Test tube agar method of 50 seeds from each of Master-B, Entsar 1, Entsar 2 and Sugar gum cultivars revealed incidence of 10 species, representing 8 fungi genera. These fungi were isolated from different seedling parts. Scanning electron microscopy (SEM) was used to examine seed borne fungi in dry seed surface of two pea cultivars Cambados (curly) and Oregon sugar (smooth).The curly cultivar hosted more fungi than the smooth one. Six categories of discoloration pea seeds were investigated using agar plate method. A total of 27 species, representing 19 genera were isolated and identified from pea seeds with different color categories. The effect of discoloration on seed characters and germination were examined. Discoloration of deteriorated seeds was associated with decreased total protein, total phenols, weight of 1000 dry seeds and seed germination percentages comparing with healthy ones. On the contrary, moisture contents in healthy seeds recorded lower percent compared with all discoloration seed categories and insect infection.
\end{abstract}

Key words: Pea-seed borne fungi, blotter method, test tube agar method, pea seed discoloration, scanning electron microscopy (SEM).

\section{INTRODUCTION}

Pea (Pisum sativum L.) belongs to leguminoceae family, which has an important ecological advantage for its contributes to the developments of low-input farming systems by fixing atmospheric nitrogen and it serves as a break crop which further minimizes the need for external inputs. Legumes constitute the third largest family of flowering plants, comprising more than 650 genera and 18.000 species (Lewis et al., 2005).

Peas are grown all over the world for its fresh use, preservation, high level of digestibility, which is more than the most of the legumes. Dried peas have been found to contain $23.5 \%$ crude protein, $1.7 \%$ ether extract and
2.9\% ash (Igbasan et al., 1997). In Egypt, pea pods are harvested for human consumption as a fresh vegetables or freezing. Legumes also accumulate natural products (secondary metabolites) such as isoflavonoids that are considered beneficial to human health through anticancer and other health-promoting activities (Dixon and Sumner, 2003). There are several factors which are responsible for their low production, among them diseases which played an important role (Nine 1986; Pal 1996).

Sonawane et al. (2004) reported that seed samples of some pea cultivars collected from India were analyzed by agar plate or blotter method for the presence of seed borne fungi.Aspergillus flavus, Aspergillus niger, Fusarium moniliforme (Gibberella moniliformis),

Corresponding author: Tel. : +201122962622

E-mail address: mmelhakeem@yahoo.com 
F. roseum, Macrophomina phaseolina, Mucor globosus, Helminthosporium tetramera (Cochliobolus spicifer) and Rhizopus nigricans ( $R$. stolonifer) were dominant. The agar plate method yielded a higher number of fungi than the standard blotter method.

Ali et al. (1982) tested 214 samples of commercial field pea seeds using a modified agar plate method. They found that $90 \%$ of samples were infected with Ascochyta pinodes (Berk and Blox) Jones, with levels of infection ranging from $1-45 \%$, making it as the most important seed borne pathogen. Seventy two percent of seed samples were infected with Macrophomina phaseolina (Tassi) Goidanich with levels of infection ranging from $1-35 \%$. Thirty-one and $24 \%$ of seed samples were infected with Phoma medicaginis (Jones) Boerema and Fusarium oxysporum Schl. f.sp. pisi, respectively. Only $10 \%$ of samples were free from infection. Michall et al. (1998) showed that, pea seeds considered an important source of Ascochyta blight in Egypt. The level of Ascochyta seed borne infection had an impact on disease severity of the growing plants. Seed samples with a high level of Ascochyta infection (34 and 32\%) sown in cultivated soil resulted in significant blight and seed infection as well as significant reduction in seed yield of the new crop. Ozgonen and Merve (2011) reported that the seed mycoflora of pea were changed according to seed groups with or without surface sterilization. The most common isolated fungi were Fusarium spp., Alternaria spp., Macrophomina phaseolina, Phytophthora megasperma, Rhizoctonia solani and Sclerotium rolfsii. Also Wilman (2014) suggested that Alternaria spp. were the most common fungi associated with pea seed in Poland, followed by Fusarium spp., Stemphylium spp., Ulocladium spp., Botrytis cinerea, Epicoccum nigrum and Phoma pinodella. There was variation in association of fungi in different cultivars and in different season. The fodder cultivar displayed a lower infection level than edible cultivar. They concluded that Alternaria spp. were the most frequent fungi present in pea seeds and Fusarium spp. were likely the most dangerous, having in mind their established mycotoxigenic ability.

El-Wakil et al. (2011) used Scanning Electron Microscopy (SEM) to study fungi colonization, infection and establishment on different sesame seed parts infected with Macrophomina phaseolina. They clearly detected successful colonization of $M$. phaseolina to seed tissues associated with different forms of pycnidial shapes were observed.

Seed borne pathogens might cause seed abortion, seed rot, seed necrosis, reduction or elimination of germination capacity as well as seedling damage resulting in development of diseases at later stages of plant growth by systemic or local infection (Bateman and Kwasna, 1999). Losses in seed quality occur during field weathering, harvesting and storage. Several factors contribute to the susceptibility for seed deterioration. The basic causes are temperature, relative humidity and seed moisture content. Invasion and tissues damage caused by microorganisms or insects. The rate of deterioration fluctuates critically from one species to another and also among varieties of the same species (Jatoi et al., 2001). Seed borne fungi affect adversely to nutritive value of pulses. Biodegradation of protein content of pulses by their common and dominant seed borne fungi like Aspergillus flavus, A.fumigatus, A.niger, Drechslera tetramera, Fusarium moniliforme, Rhizopus stolonifer etc. has been reported through artificial infestation of the pulses like green gram, black gram, chickpea and pigeon pea. Results reveal considerable degradation in protein content of the test pulses (Kandhare, 2014).

The present study aims to isolate and identify the seed borne fungi associated with pea (Pisum sativum L.) grown under Egyptian condition, using various different methods of seed health testing. Scanning electron microscopy (SEM) was also used to study the relation between pea seed surface and contaminated fungi. The effect of natural infection by fungi in field on seeds component and germination was also studied.

\section{MATERIALS AND METHODS}

\section{Seed Samples}

Seed samples of different cultivars were collected from the major pea growing fields from Egypt Governorates including Ismailia (5 samples), Sharkia (11), Kalubiya (4), Dakahliay 
(4), Dimyata (5), Behera (7) and Beni-Swef (7). In addition, other seed samples were also obtained from Horticulture Research Institute (4) and Central Administration of Seed Production (2) during 2011-2016 were included in this study. The weight of each sample was 350 gram. The samples stored in sterilized paper bags and transferred directly to the laboratory at ambient storage temperature of $28 \pm 2$ for further studies.

\section{Seed Health Testing}

Detection of seed borne fungi was carried out using the following procedures which published by the International Seed Testing Association (ISTA, 1999 and 2008). Seeds investigation was carried out using blotter, agar plate and test tube agar methods.

\section{Blotter method}

Forty five pea seed samples of master-B cultivar were investigated using blotter method. Eight hundred seeds of each sample were tested and divided into two groups; first group was undisinfested seeds and the second one was surface disinfected in $1 \%$ (available chlorine) sodium hypochlorite solution for $2 \mathrm{~min}$ followed by 3 successive rinses in sterile water. The excess water was removed by placing the treated seeds between two sterilized tissue paper until dryness. Replicates of ten seeds were plated in three moistened blotters with distilled water in 9- $\mathrm{cm}$ diameter sterile Petri dishes. The plates were incubated at $20 \pm 2^{\circ} \mathrm{C}$ for 7 days under 12 hours cool white fluorescent light with alternating cycles of 12 hours darkness.

\section{Agar plate method}

The preparations and procedures were the same as for blotter method except that the medium in Petri dishes was potato dextrose agar.

\section{Test tube agar method}

In this method, symptoms can easily studied being visible on roots as well as green parts. Fifty seeds of each variety Master-B, Entsar 1, Entsar 2 and Sugar gum obtained from Horticulture Research Institute were tested for detection of seed borne fungi using test tube agar described by Khare et al. (1977).
Isolation, Purification and Identification of Seed Borne Fungi

After seven days incubation of each previously three used method, incubated seeds were examined under a stereoscopic microscope (6-50 X magnification) to detect seed borne fungi and study their morphological characteristics. Whenever necessary, a compound microscope was used to confirm the identification. In consultation with Commonwealth Mycological Institute description sheets, Danish Government Institute of Seed Pathology publication, the fusarium laboratory manual and research work of Gilman (1957), Barnet and Hunter (1972), Nelson et al. (1983), Booth (1985), Burgess et al. (1988), Singh et al. (1991) and Tadja et al. (2009)were used to confirm the obtained results.

Scanning Electron Microscopy (SEM) Applied to Seed Borne Fungi Examination in Blotter Method

Techniques of fungal observation in infected seeds with light microscope and stereomicroscopy can be supplemented by alternative methods with greater precision using Scanning Electron Microscopy as a complementary methodology to identify seed borne fungi using SEM according to Alves et al. (2013).

Two experiments were carried out in the first one, dry seeds of two pea cultivars i.e. Cambados (curly) and Oregon sugar (Smooth) collected from greenhouse experimental were surface scanning. In the second test 400 seeds of Master-B seeds were submitted to blotter method, and then examined using (SEM -JEOL JSM 6510 IV) at Scanning Electron Microscopy Center, Fac. Agric., El-Mansoura University, Egypt. The digital images were generated, filtrated and recorded using the computer.

\section{Percentage Incidence of Seed Borne Fungi in Six Discoloration Categories of Natural Infection Pea Seeds}

Pea seed samples Master-B were visually inspected and graded into six categories according to seed discoloration: 1) Apparently healthy seeds; 2) Seeds with yellow and brown spots; 3) Seeds with untypical spots; 4) Small and malformed seeds; 5) Insect infection appearance; 6) Mechanical broken seed coat. Randomly 400 seeds were taken from each 
category of discolored pea seeds and investigated for percentage incidence of seed borne fungi using potato dextrose agar method.

\section{Effect of Seed Discoloration on Seed Germination and Characters}

Total protein estimation was done by Lowry's method according to Wadje and Baig (2006) and total phenolic compounds were determined using the Folin-ciocalteau method (Singleton et al., 1999) in healthy and discolored pea seed category samples. Also the germinability tests were carried out according to the international rule of seed testing ISTA (1993). Moisture content of seeds was determined according to the method of AOAC (1980). Finally the weight of 1000 seeds was recorded.

\section{Data Analysis}

The data were statistically analyzed by using Completely Randomized Design (CRD) as suggested by Gomez and Gomez (1984).

\section{RESULTS AND DISCUSSION}

\section{Blotter Method}

Results in Table 1 show that a total number of 28 species, representing 19 genera of fungi were isolated from pea seeds by blotter method test. The highest percentages incidence of isolated fungi from disinfested seeds were Alternaria alternata (1.91\%), Fusarium oxysporum (0.93\%), Alternaria tenuis $(0.84 \%)$, Fusarium poae (0.69\%), Aspergillus niger (0.36\%), Aspergillus tmarii (0.31\%), Fusarium solani (0.29\%), Rhizoctonia solani (0.28\%), Acromoinum strictum (0.27\%), and Stemphylium botryosum $(0.27 \%)$. The moderately incidence percentage of isolated fungi were Penicillium sp. (0.23\%), Aspergillus flavus (0.22\%), Cladosporium herbarum (0.22\%), Chaetomium globosum $(0.21 \%)$, Fusarium equiseti $(0.21 \%)$ and Sclerotinia sclerotiorum $(0.21 \%)$ while the lowest incidence percentage of isolated fungi from disinfested seeds were Botrytis cinerea (0.10\%), Rhizopus stolonifer (0.09\%), Trichoderma harazinum (0.09\%), Myrothecium sp. $(0.06 \%)$ and Fusarium avenaceum $(0.04 \%)$. On the other hand, some fungi were not detected in disinfested seeds as Botryodiplodia theobromae, Mucor hiemalis and Trichothecium $\mathrm{sp}$. The results indicated that these fungi are externally infested seeds.

Results in Table 1 also show that the highest incidence percentages of isolated fungi from undisinfested seeds were Alternaria alternata (Fr.)Keissler (4.02\%), Alternaria tenuis Auct. (1.63\%), Fusarium poae (Peck) Woll. (0.88\%), Cladosporium herbarum (Pers.: Fr.) Link (0.87\%), Aspergillus niger Tieg. (0.83\%), Penicillium sp. (0.83\%), Aspergillus flavus (Link) Fr. (0.79\%) and Stemphylium botryosum Wallr. $(0.68 \%)$.The moderately incidence percentage of isolated fungi were Botryodiplodia thiobromae $(0.20 \%)$ and Myrothecium sp. $(0.24 \%)$ while, the lowest incidence percentages of isolated fungi were Fusarium avenaceum $(0.02 \%)$, Fusarium equiseti ( $0.04 \%)$, Trichothecium sp. $(0.06 \%)$ and Fusarium moniliforme $(0.06 \%)$, respectively. Similar results of isolated pea seed borne fungi were obtained by Ali et al. (1982), Abdel-Hafez (1984), Czyzewska (1993), Marcinkowska (1997), Saber et al. (1998), Begum et al. (2004) and Narayan and Ayodhya (2013).

\section{Agar Plate Method}

Results in Table 2 show that the highest incidence percentages of isolated fungi from disinfested seeds were Fusarium oxysporum (1.28\%), Alternaria alternata (1.10\%), Trichoderma harazinum (0.72\%), Acromoinum strictum (0.53\%) and Nigrospora sp. (0.53\%). The moderately incidence percentages of isolated fungi were Alternaria tenuis (0.49\%), Fusarium poae (0.49\%), Epicoccum purpurascens $(0.41 \%)$, Rhizoctonia solani $(0.39 \%)$, Penicillium sp. (0.36\%), Aspergillus flavus (0.32\%), respectively.

The results also showed that some fungi were not detected in disinfested seeds as Botryodiplodia theobromae, Chaetomium globosum, Fusarium pogonea, Mucor hiemalis, Myrothecium sp. and Trichothecium sp. Also results in Table 2 observed that the highest incidence percentages of isolated fungi from undisinfected seeds in agar plate method were Alternaria alternata (2.13\%), Rhizopus stolonifer (1.06\%), Acromoinum strictum (0.98\%), Trichoderma 
Table 1. Incidence of seed borne fungi in $\mathbf{4 5}$ seed samples of pea using blotter method

\begin{tabular}{|c|c|c|c|c|c|c|c|c|}
\hline \multirow[t]{2}{*}{ Isolatd fungi } & \multicolumn{4}{|c|}{ Disinfested seeds } & \multicolumn{4}{|c|}{ Undisinfested seeds } \\
\hline & NSI & $\begin{array}{c}\text { Occurrenc } \\
(\%)\end{array}$ & $\begin{array}{c}\text { Infection } \\
(\%)\end{array}$ & $\begin{array}{l}\text { Range of } \\
\text { infection }\end{array}$ & NSI & $\begin{array}{c}\text { Occurrence } \\
(\%)\end{array}$ & $\begin{array}{c}\text { Infection } \\
(\%)\end{array}$ & $\begin{array}{l}\text { Range of } \\
\text { infection }\end{array}$ \\
\hline Acromoinum strictum & 6 & 13.33 & 0.27 & $1-5$ & 10 & 22.22 & 0.60 & $1-7$ \\
\hline Alternaria alternata & 26 & 57.77 & 1.91 & $1-9.5$ & 32 & 71.11 & 4.02 & $3.75-15.5$ \\
\hline Alternaria tenuis & 23 & 51.11 & 0.84 & $1-2$ & 24 & 53.33 & 1.63 & $2.75-3.5$ \\
\hline Aspergillus flavus & 5 & 11.11 & 0.22 & $1.5-2.75$ & 15 & 33.33 & 0.79 & $0.5-4.5$ \\
\hline Aspergillus niger & 11 & 24.44 & 0.36 & $0.5-3$ & 24 & 53.33 & 0.83 & $1-2$ \\
\hline Aspergillus tmarii & 12 & 26.67 & 0.31 & $0.5-3$ & 15 & 33.33 & 0.62 & $0.5-4.5$ \\
\hline Botryodiplodia theobromae & 0 & 0.0 & 0.0 & 0.0 & 3 & 6.67 & 0.20 & $2-4$ \\
\hline Botrytis cinerea & 5 & 11.11 & 0.10 & $0.75-1.5$ & 10 & 22.22 & 0.55 & $0.5-5$ \\
\hline Chaetomium globosum & 8 & 17.78 & 0.21 & $0.5-1.5$ & 13 & 28.89 & 0.34 & $0.5-2.5$ \\
\hline Cladosporium herbarum & 9 & 20.00 & 0.22 & $1-1.5$ & 19 & 42.22 & 0.87 & $1-3$ \\
\hline Epicoccum purpurascens & 5 & 11.11 & 0.18 & $1-3$ & 8 & 17.78 & 0.45 & $0.5-6$ \\
\hline Fusarium avenaceum & 2 & 4.44 & 0.04 & 1.0 & 1 & 2.22 & 0.02 & 1.0 \\
\hline Fusarium equiseti & 8 & 17.78 & 0.21 & $0.5-3.25$ & 2 & 4.44 & 0.04 & $0.5-1.5$ \\
\hline Fusarium moniliforme & 7 & 15.56 & 0.16 & $0.5-1.5$ & 3 & 6.67 & 0.06 & $0.5-1.75$ \\
\hline Fusarium oxysporum & 13 & 28.89 & 0.93 & $1-4.5$ & 12 & 26.67 & 0.39 & $1-2.25$ \\
\hline Fusarium poae & 11 & 24.44 & 0.69 & $1-5.25$ & 16 & 35.55 & 0.88 & $0.5-5.5$ \\
\hline Fusarium pogonea & 5 & 11.11 & 0.11 & $0.25-1.5$ & 10 & 22.22 & 0.29 & $0.5-2.25$ \\
\hline Fusarium solani & 9 & 20.00 & 0.29 & $0.5-3$ & 8 & 17.78 & 0.33 & $0.75-3$ \\
\hline Mucor hiemalis & 0 & 0.0 & 0.0 & 0.0 & 5 & 11.11 & 0.51 & $4-5$ \\
\hline Myrothecium sp. & 3 & 6.67 & 0.06 & $0.5-1$ & 6 & 13.33 & 0.24 & $0.75-2.75$ \\
\hline Nigrospora sp. & 5 & 11.11 & 0.18 & $0.5-3$ & 10 & 22.22 & 0.36 & $0.75-3.5$ \\
\hline Penicillium sp. & 7 & 15.56 & 0.23 & $1-4$ & 16 & 35.55 & 0.83 & $1-7$ \\
\hline Rhizoctonia solani & 9 & 20.00 & 0.28 & $0.5-2.75$ & 15 & 33.33 & 0.47 & $0.5-3$ \\
\hline Rhizopus stolonifer & 3 & 6.67 & 0.09 & $1-2$ & 10 & 22.22 & 0.81 & $1.25-12.5$ \\
\hline Sclerotinia sclerotiorum & 7 & 15.56 & 0.21 & $0.75-3$ & 7 & 15.56 & 0.29 & $1-4$ \\
\hline Stemphylium botryosum & 12 & 26.67 & 0.27 & $0.25-4$ & 14 & 31.11 & 0.68 & $0.75-6$ \\
\hline Trichoderma harazinum & 5 & 11.11 & 0.09 & $0.5-1$ & 5 & 11.11 & 0.53 & $1.25-8$ \\
\hline Trichothecium sp. & 0 & 0.00 & 0.0 & 0.0 & 4 & 8.89 & 0.06 & $0.5-1$ \\
\hline LSD at $0.05 \%$ & \multicolumn{4}{|c|}{0.08} & \multicolumn{4}{|c|}{0.12} \\
\hline
\end{tabular}


Table 2. Incidence of seed borne fungi in 45 seed samples of pea using agar plate method

\begin{tabular}{|c|c|c|c|c|c|c|c|c|}
\hline \multirow[t]{2}{*}{ Isolated fungi } & \multicolumn{4}{|c|}{ Disinfected seeds } & \multicolumn{4}{|c|}{ Undisinfested seeds } \\
\hline & NSI & $\begin{array}{c}\text { Occurrence } \\
(\%)\end{array}$ & $\begin{array}{c}\text { Infection } \\
(\%)\end{array}$ & $\begin{array}{l}\text { Range of } \\
\text { infection }\end{array}$ & NSI & $\begin{array}{c}\text { Occurrence } \\
(\%)\end{array}$ & $\begin{array}{c}\text { Infection } \\
(\%)\end{array}$ & $\begin{array}{l}\text { Range of } \\
\text { infection }\end{array}$ \\
\hline Acromoinum strictum & 8 & 17.78 & 0.53 & $2-6$ & 9 & 20.00 & 0.98 & $2.5-9$ \\
\hline Alternaria alternata & 18 & 40.00 & 1.10 & $1-7$ & 28 & 62.22 & 2.13 & $1-8.75$ \\
\hline Alternaria tenuis & 19 & 42.22 & 0.49 & $0.75-1.5$ & 23 & 51.11 & 0.86 & $0.75-2.75$ \\
\hline Aspergillus flavus & 7 & 15.56 & 0.32 & $0.75-4$ & 9 & 20.00 & 0.58 & $0.75-6$ \\
\hline Aspergillus niger & 11 & 24.44 & 0.32 & $0.5-3$ & 22 & 48.89 & 0.53 & $0.5-2$ \\
\hline Aspergillus tmarii & 5 & 11.11 & 0.18 & $0.25-4$ & 13 & 28.89 & 0.67 & $0.5-3.75$ \\
\hline Botryodiplodia theobromae & 0 & 0.0 & 0.0 & 0.0 & 8 & 17.78 & 0.15 & $0.25-3$ \\
\hline Botrytis cinerea & 4 & 8.89 & 0.18 & $1-3$ & 9 & 20.00 & 0.61 & $1.75-4$ \\
\hline Chaetomium globosum & 0 & 0.0 & 0.0 & 0.0 & 5 & 11.11 & 0.10 & $0.5-1.5$ \\
\hline Cladosporium herbarum & 3 & 6.67 & 0.09 & $1-1.5$ & 14 & 31.11 & 0.53 & $1-4$ \\
\hline Epicoccum purpurascens & 8 & 17.78 & 0.41 & $0.5-9$ & 5 & 11.11 & 0.37 & $1.75-6$ \\
\hline Fusarium avenaceum & 4 & 8.89 & 0.07 & $0.5-1$ & 2 & 4.44 & 0.03 & $0.5-1$ \\
\hline Fusarium equiseti & 6 & 13.33 & 0.12 & $0.5-1$ & 1 & 2.22 & 0.01 & 0.5 \\
\hline Fusarium moniliforme & 3 & 6.67 & 0.06 & $0.5-1.75$ & 3 & 6.67 & 0.15 & $1-3$ \\
\hline Fusarium oxysporum & 17 & 37.78 & 1.28 & $0.5-7$ & 13 & 28.89 & 0.75 & $1.5-5$ \\
\hline Fusarium poae & 10 & 22.22 & 0.49 & $1-5.25$ & 8 & 17.78 & 0.20 & $0.5-4$ \\
\hline Fusarium pogonea & 0 & 0.0 & 0.0 & 0.0 & 2 & 4.44 & 0.06 & $0.5-2$ \\
\hline Fusarium solani & 5 & 11.11 & 0.10 & $0.5-1$ & 3 & 6.67 & 0.09 & $1.25-2$ \\
\hline Mucor hiemalis & 0 & 0.0 & 0.0 & 0.0 & 3 & 6.67 & 0.78 & $5-25$ \\
\hline Myrothecium sp. & 0 & 0.0 & 0.0 & 0.0 & 3 & 6.67 & 0.07 & 1.0 \\
\hline Nigrospora sp. & 10 & 22.22 & 0.53 & $0.5-7$ & 11 & 24.44 & 0.57 & $1.5-4.5$ \\
\hline Penicillium spp. & 8 & 17.78 & 0.36 & $0.5-5$ & 15 & 33.33 & 0.81 & $0.75-8$ \\
\hline Rhizoctonia solani & 14 & 31.11 & 0.39 & $0.5-2.5$ & 15 & 33.33 & 0.34 & $0.5-3$ \\
\hline Rhizopus stolonifer & 4 & 8.89 & 0.22 & 2.5 & 8 & 17.78 & 1.06 & $2.5-12.5$ \\
\hline Sclerotinia sclerotiorum & 7 & 15.56 & 0.26 & $0.5-6$ & 7 & 15.56 & 0.48 & $1.5-8$ \\
\hline Stemphylium botryosum & 7 & 15.56 & 0.29 & $0.5-6$ & 11 & 24.44 & 0.77 & $1-5$ \\
\hline Trichoderma harazinum & 5 & 11.11 & 0.72 & $3-8$ & 6 & 13.33 & 0.91 & $1-10$ \\
\hline Trichothecium spp. & 0 & 0.0 & 0.0 & 0.0 & 7 & 15.56 & 0.21 & $0.5-2.75$ \\
\hline LSD at $0.05 \%$ & \multicolumn{4}{|c|}{0.06} & \multicolumn{4}{|c|}{0.17} \\
\hline
\end{tabular}


harazinum $(0.91 \%)$, Alternaria tenuis $(0.86 \%)$, Penicillium sp., (0.81\%), Mucor hiemalis (0.78\%), Stemphylium botryosum (0.77\%), Fusarium oxysporum (0.75\%), Aspergillus tmarii (0.67\%), Botrytis cinerea (0.61\%), Aspergillus flavus (0.58\%), Nigrospora sp. (0.57\%), Aspergillus niger $(0.53 \%)$ and Cladosporium herbarum $(0.53 \%)$ while, the lowest incidence percentages of the isolated fungi from undisinfested seeds in agar plate method were Fusarium equiseti (0.01\%), Fusarium avenaceum (0.03\%), Fusarium pogonea $(0.06 \%)$, Myrothecium sp. (0.07). Similar results of isolated pea seed borne fungi were obtained by Sonawane et al. (2004).

In general results in Tables 1 and 2 show that blotter and agar plate method revealed the same fungal species, 28 species, representing 19 genera of fungi isolated from pea seeds.

In addition the agar plate method was more accurate for detection of most isolated seed borne fungi percentages on pea seeds comparing with blotter one. These results are in agreement with the findings of Gill et al. (1983) on some Nigerian leguminous seeds, Abdel-Al (1994) on alfalfa seeds, Shakir and Mirza (1994) on chickpea seed, Solanke et al. (1997) on soybean seeds, Godika et al. (1999) on sunflower, Sonawane et al. (2004) on pea and Shaker et al. (2010) who suggested that nutrients from the media might play an important role in initiation of growth of fungi on pulses. We suggested that seed leaching as a removal substances from seeds in blotter method such as sugars, amino acids and other chemicals played a very important roles in encourage or suppression the fungus growth mycelium and spore germination. Also Singh et al. (2017) reported that legumes are a good source of bioactive phenolic compounds which played significant roles in many physiological, as well as, metabolic processes. Phenolic acid, flavonoids and condensed tannins are the primary phenolic compounds that are present in legume seeds which affected on recovery fungi. On the contrary, other research workers reported that blotter method test was found superior in isolation of more number of fungal colonies over agar plate one. These results are in the same trend of Dawar (2005) on chickpea seeds, Tariq et al. (2005) and Venugopal et al. (2015) on soybean.
Blotter method was preferable for detecting some seed borne fungi with the percentage of infection in disinfested and undisinfested seeds, respectively such as Alternaria alternata (1.914.02), Alternaria tenuis (0.84-1.63), Aspergillus niger (0.36-0.83), Chaetomium globosum (0.210.34), Cladosporium herbarum (0.22-0.87), Fusarium poae (0.69-0.88), Fusarium solani (0.29-0.33), Myrothecium sp. (0.06-0.24) respectively. Also, the obtained results showed that blotter and agar plate tests could not be used singly for seed borne fungi detection but more than one method must be used. Results of this study were in accordance with those obtained on soybean and four other crops by Agarwal et al. (1972), on lucerne (Singh and Gupta, 1984), on soybean (El-Gantiry 1985), on alfalfa (Abdel-Al, 1994) and Rathod et al. (2012) on groundnut seeds.

The most characterized feature observed is that total count of fungi, and number of infected samples was slightly higher in undisinfested samples than disinfested samples in both tested methods and are in agreement with findings of Ozgonen and Merve (2011) and Dawar et al. (2015). They reported that seed mycoflora were changed according to seed groups, with or without surface sterilization. On the other hand, Fusarium spp. were detected in disinfested seeds of pea in both tested methods at the highest rate compared with undisinfested seeds. The removal of externally seed borne fungi by surface disinfestation with $1 \%$ (available chlorine) sodium hypochlorite solution for 2 min proved to be suitable method for isolating the internally seed borne fungi of pea. These results are in agreement with finding of Perveen Shahida and Abdul Ghaffar (1995) who proved that surface disinfestation provides a chance for the internally seed borne fungi to appear in greater number, also with the recommended by (ISTA, 1993). The recovery of most isolated fungi in blotter and agar plate method even after surface sterilization of seeds indicated the presence of these fungi inside as well as on the surface of the seeds. The results are in agreement with findings of Ozgonen and Merve (2011) and Ramesh et al. (2013).

\section{Test Tube Agar Method}

Results in Table 3 show that 10 species, representing 8 genera of fungi, were isolated from 
Table 3. Isolated fungi from undisinfested pea seed cultivars as healthy seeds, seeds rot and seedling blight using test tube agar method after 14 days

\begin{tabular}{|c|c|c|c|c|c|}
\hline Cultivar and & Healthy-looking & Seed & Seedling & Recovery fungi (\%) & Percentage \\
\hline isolated fungi & $\begin{array}{l}\text { seedilngs } \\
(\%)\end{array}$ & $\begin{array}{l}\text { rot } \\
(\%)\end{array}$ & $\begin{array}{l}\text { blight } \\
(\%)\end{array}$ & $\begin{array}{c}\text { Seedling } \\
\text { blight }\end{array}$ & $\begin{array}{l}1 \text { recovery } \\
\text { fungi }\end{array}$ \\
\hline
\end{tabular}

Master-B

Alternaria alternata

Stemphylium botryosum

Aspergillus flavus

Cladosporium sp

Epicoccum sp.

Fusarium solani

Entsar 1

Alternaria alternata

Cladosporium sp

Aspergillus niger

Nigrospora sp.

Entsar 2

Alternaria alternata

Cladosporium sp

Rhizctonia solani

Sugar gum

Alternaria alternata

Cladosporium sp

Aspergillus niger

Fusarium oxysporum

Fusarium solani

Total percentage

\begin{tabular}{|c|c|c|c|c|c|}
\hline 80 & 14 & 6 & - & - & - \\
\hline- & - & - & 4 & 2 & 6 \\
\hline- & - & - & 2 & 0 & 2 \\
\hline- & - & - & 6 & 0 & 6 \\
\hline- & - & - & 0 & 2 & 2 \\
\hline- & - & - & 2 & 0 & 2 \\
\hline- & - & - & 4 & 0 & 4 \\
\hline \multirow[t]{2}{*}{90} & 6 & 4 & - & - & - \\
\hline & - & - & 2 & 2 & 4 \\
\hline- & - & - & 0 & 2 & 2 \\
\hline- & - & - & 6 & 0 & 6 \\
\hline- & - & - & 2 & 0 & 2 \\
\hline 96 & 4 & 2 & - & - & - \\
\hline- & - & - & 4 & 2 & 6 \\
\hline- & - & - & 0 & 2 & 2 \\
\hline- & - & - & 6 & 0 & 6 \\
\hline 88 & 10 & 2 & - & - & - \\
\hline- & - & - & 0 & 2 & 2 \\
\hline- & - & - & 0 & 2 & 2 \\
\hline- & - & - & 4 & 0 & 4 \\
\hline- & - & - & 6 & 0 & 6 \\
\hline- & - & - & 2 & 0 & 2 \\
\hline- & - & - & 50 & 16 & 66 \\
\hline
\end{tabular}

different seedling parts of four pea cultivars, on water agar medium. The total recovery fungi percentage from rotted seeds were $(50 \%)$ while from seedling blight were $(16 \%)$.The rotted seeds percentages in Master-B, Entsar1, Entsar2 and Sugar gum were $14,6,4$ and $10 \%$ while seedling blight percentages were $6,4,2$ and $2 \%$, respectively.
The results shown in (Fig.1-a,b) show healthy seedling developed from healthy seeds. Meanwhile, natural infected seedling might escape and survival (Fig. 1-c) and heavily infected seeds with Fusarium spp. and Rhizoctonia sp. were recovered and germinate (Fig. 1-d,e,f) and the seedling died at the early stage of the plant growth also Fig. (1-g) show 


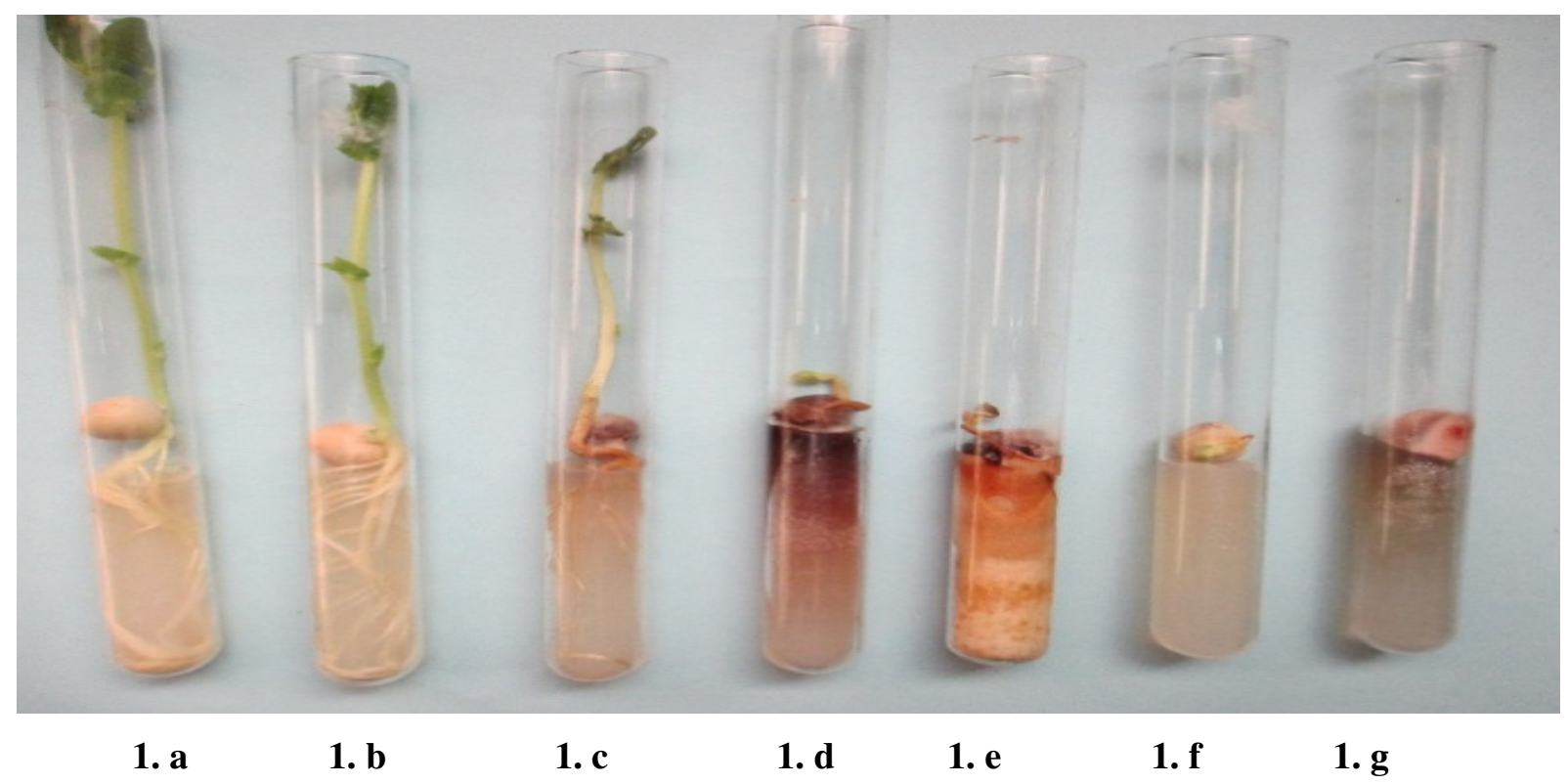

Fig. 1a-g. Pea seedling (14 days old) developing in test tube agar method showing different symptoms of diseases resulting from naturally infected seeds

heavily infected seed that covered with the Fusarium spp. growth and failed to germinate. These results are agreement partialy with those obtained by El-Gantiry (1985) and Abdel-Al (1994). In test tube agar method seed germination and seedling development under controlled conditions both of infected seed and seedling may develop symptoms comparable to those developed under field conditions and provide valuable information pertaining to field performance of the sowing seeds.

\section{Scanning Electron Microscopy (SEM) Applied to Examine Seed Surface and its Relation to Infected Fungi}

Two experiments were carried out using SEM. In the first one, dry seeds of two pea cultivars Cambados (curly) and Oregon sugar (Smooth) were scanned to investigate the seed surface. Fig. 2-a of smooth pea seed Oregon sugar cultivar show less loads of fungal spores and fragments of fungal mycelia compared with curly pea seed Cambados cultivar (Fig. 2-b). Although the Oregon sugar seeds have cracks and ruptures that might be have more number of fungal fragments and spores. These results might be contributed in primary indicator about seed contaminated surface with fungus fragments and spores in addition smooth seeded peas do not exude as much carbohydrate and inorganic salts as do wrinkled seed peas and are thus less susceptible to seed and seedling infection Kraft (1991). We suggest that scanning electron microscopy of dry seeds might be more provide when investigating seeds for biotrophic fungi as rust, powdery mildew and downy mildew spores density. These results are in agreement with finding of Machado (2002). He reported that the groups of fungi are biotrophic and necrotrophic and specific or more selective methods are required for their reliable detection in routine analysis of various formae specialis of fungi such as Fusarium spp., Colletotrichum spp., Phomopsis spp. Thus, considering the advantages of SEM related characteristics such as increase, fast image digitalization and acquisition, easiness of preparation and operation of samples, as well as relatively accessible costs, this approach might became a viable contribution to decision support in routine seed health analysis.

In the second test, 400 pea seeds of Master-B cultivar submitted to blotter method. Seeds were subject to conditions that enable pathogen growth and expression and then prepared and observed with SEM. The images of some recovering fungi were generated as Fig. 2-c Fusarium sp., presenting macroconidia, heads and 


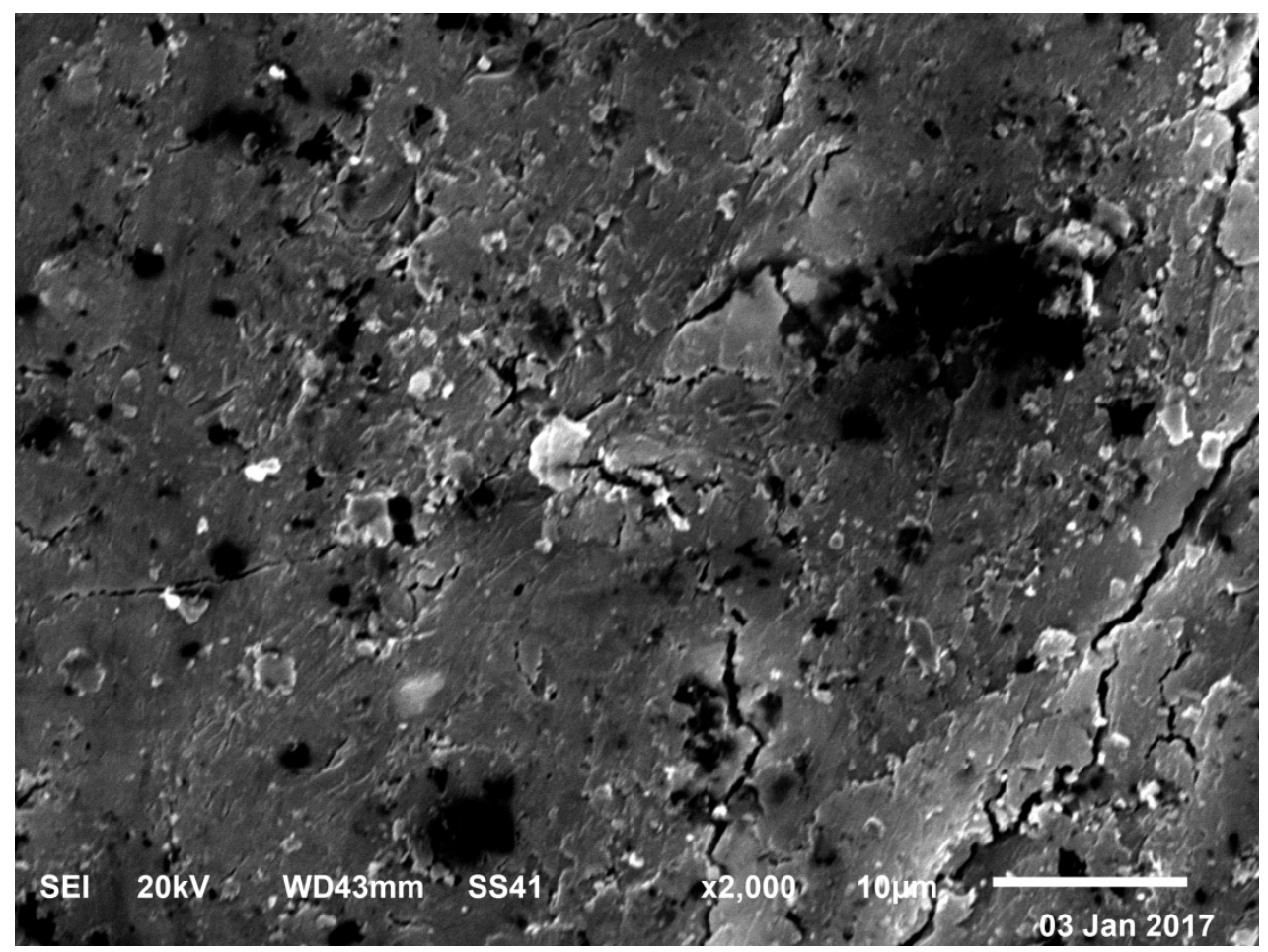

Fig. 2-a. Spherical and smooth pea seed surface (Oregon cultivar) 2000X

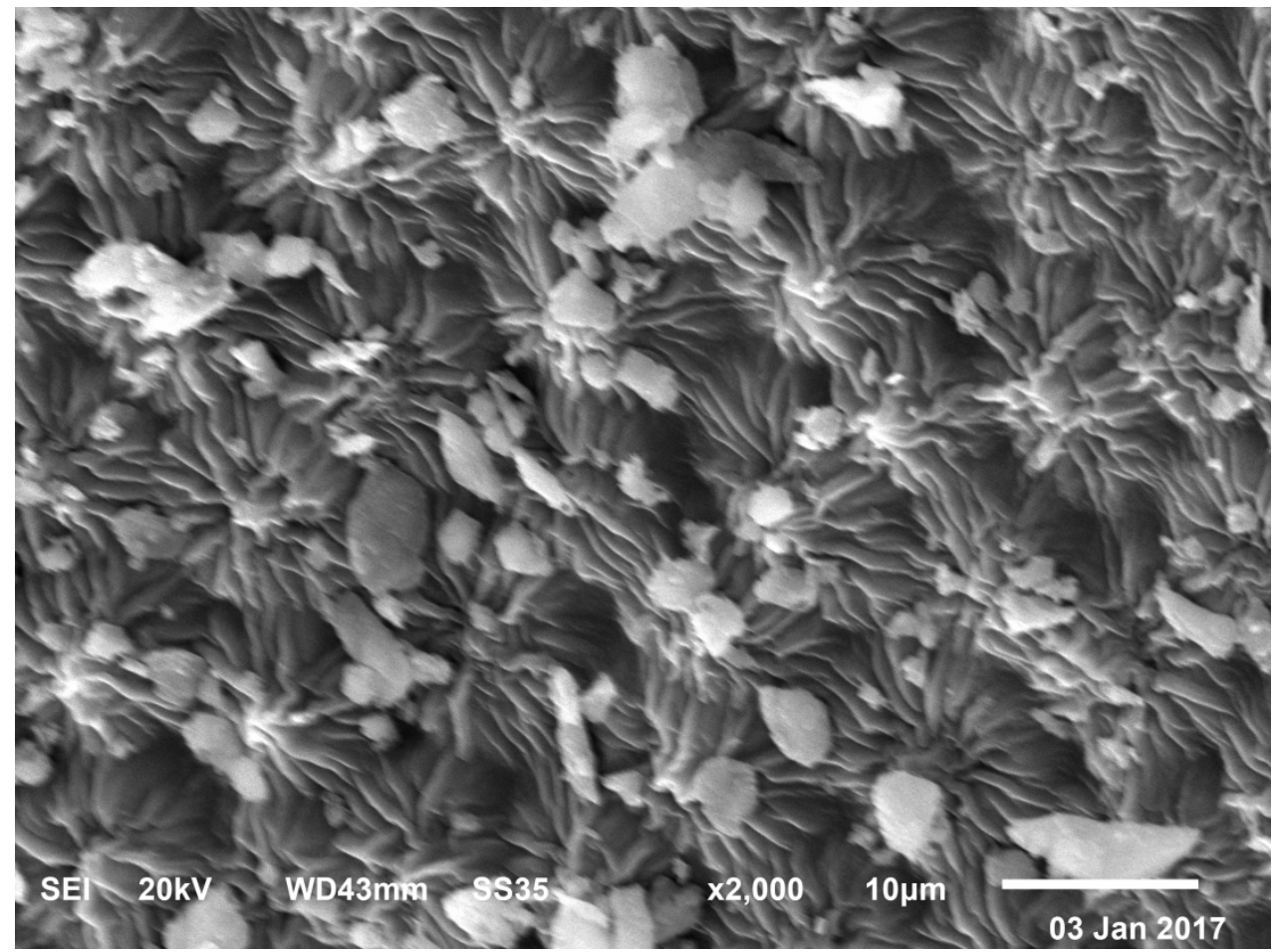

Fig. 2-b. Rough and curved pea seed surface (Cambados cultivar) 2000X 


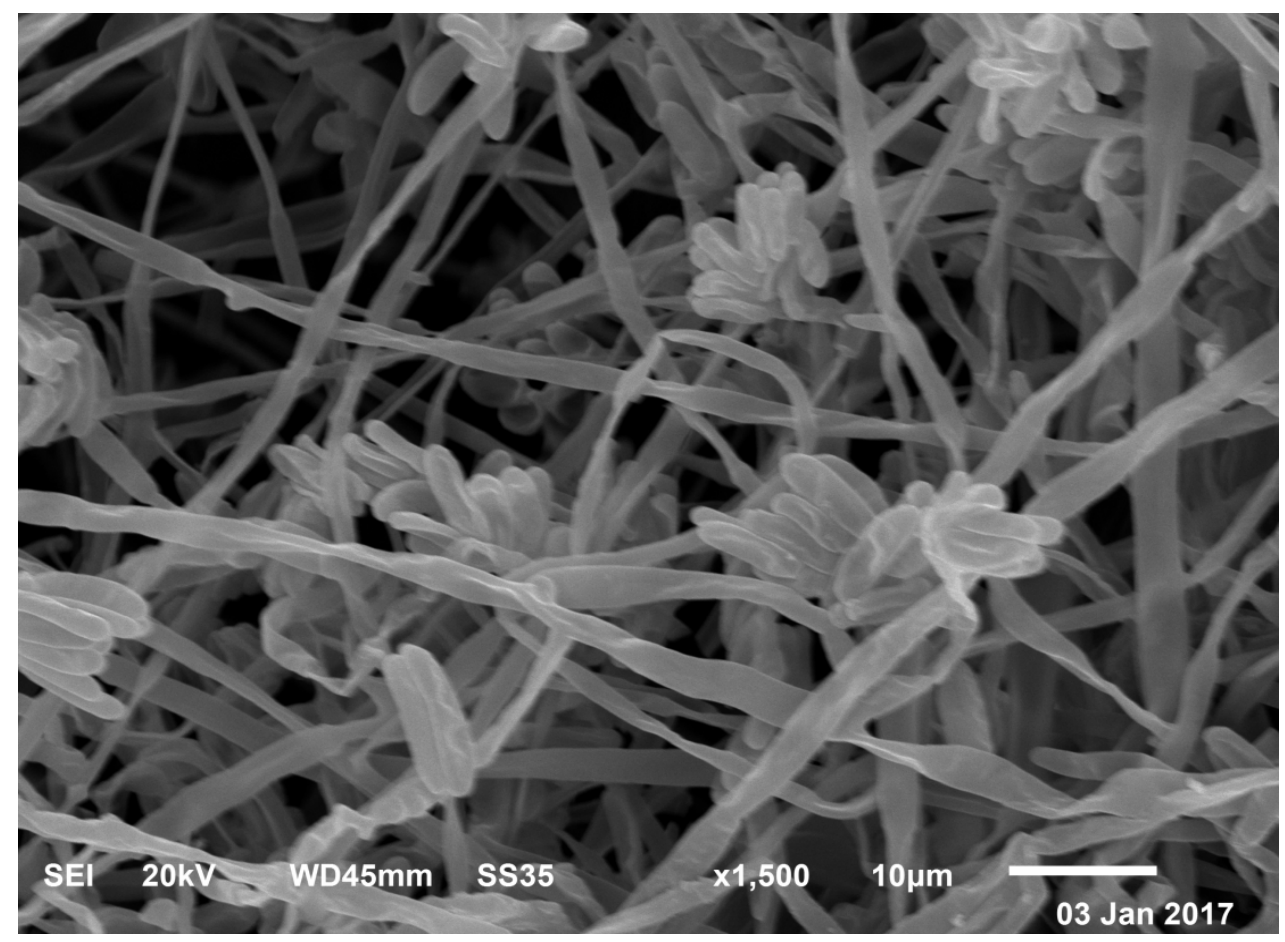

Fig. 2-c. Scanning electron photograph of pea seed surface used in laboratory diagnosis of Fusarium sp., presenting macroconidia, heads and conidium at the phialide apex (1500X)

conidium at the phialide apex. (Fig. 2-d) Botryodiplodia theobromae, presenting mycelium and pycnido spores (Fig. 2-e) Myrothecium sp. presenting colony and mycelium. Similar results were obtained on seeds of cotton, common bean and maize by Alves and Pozza (2009) and Alves et al. (2013).

\section{The Incidence of Seed Borne Fungi on Different Discoloration Categories of Pea Seeds}

Results in Table 4 indicate that a total of 27 species, representing 19 genera were isolated from pea seeds with different color (Fig. 3). The isolated fungi could be arranged according to percentages of frequency from healthy seeds as follows; both Alternaria alternata and Fusarium oxysporum (5.0\%), Aspergillu flavus (3.0\%), Alternaria tenuis (2.0\%), Fusarium solani (1.25\%), both Cladosporium herbarum, Fusarium equiseti and Fusarium poae (1.0\%), Trichoderma harazinum $(0.75 \%)$ and Nigrospora sp. $(0.25 \%)$. The most prevalent in seeds with dark brown and yellow spots were Alternaria alternata (8.0\%), Alternaria tenuis (6.5\%), Sclerotinia sclerotiorum (5.50\%), Fusarium oxysporum (3.5\%) and Chaetomium globosum (3.0\%). The most prevalent in seeds with untypical spots were Alternaria alternata (15.0\%), Alternaria tenuis (10.0\%), Sclerotinia sclerotiorum (5.25\%), both Fusarium moniliforme and Fusarium oxysporum (3.5\%). The most prevalent in seeds with Small and malformed seeds were Fusarium oxysporum (7.0\%), Nigrospora sp. (4.0\%), Alternaria alternata (3.5\%), both Acromoinum sp. and Fusarium solani (3.0\%), Alternaria tenuis (2.75\%), both Rhizoctonia solani and Sclerotinia sclerotiorum $(2.5 \%)$. The most prevalent in seeds with insect infection were Alternaria alternata (7.5\%), Aspergillu flavus (7.0\%), Sclerotinia sclerotiorum (5.0\%), Alternaria tenuis (4.75\%), Nigrospora sp. (3.0\%), and Rhizopus stolonifer (2.50\%).

The most prevalent associated fungi, in seeds with mechanical broken seed coat, were Aspergillu flavus (5.50\%), both Alternaria tenuis and Sclerotinia sclerotiorum (5.0\%), Alternaria alternata (4.5\%), Fusarium oxysporum (3.75\%), Aspergillus niger (2.75\%) and Rhizopus stolonifer (2.25\%). Similar results have also been reported by Czyzewska (1983). He stated that Ascochyta spp. produce distinctive 


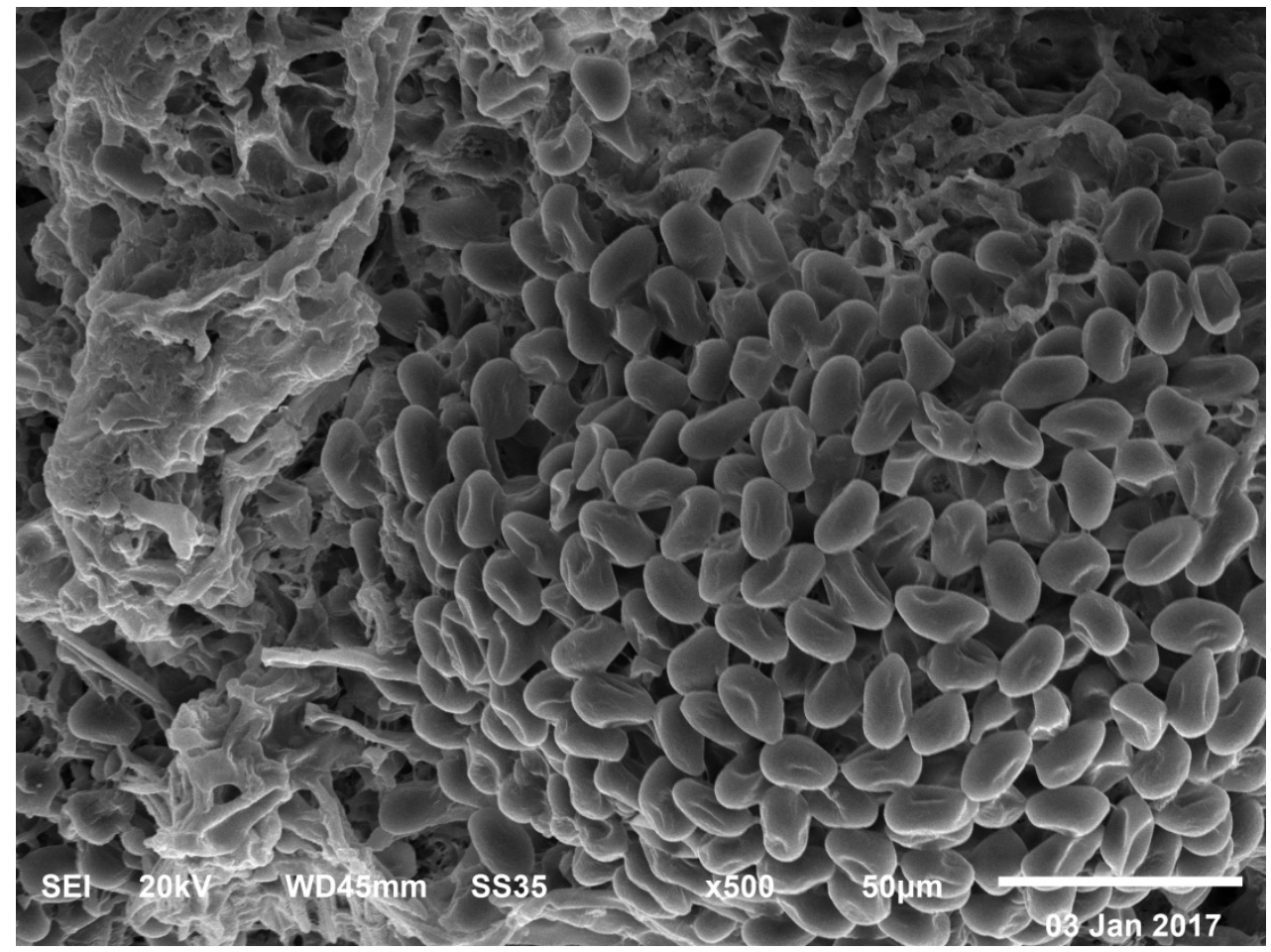

Fig. 2-d. Scanning electron photograph of pea seed surface used in laboratory diagnosis of Botryodiplodia theobromae presenting mycelium and pycnido spores (500X)

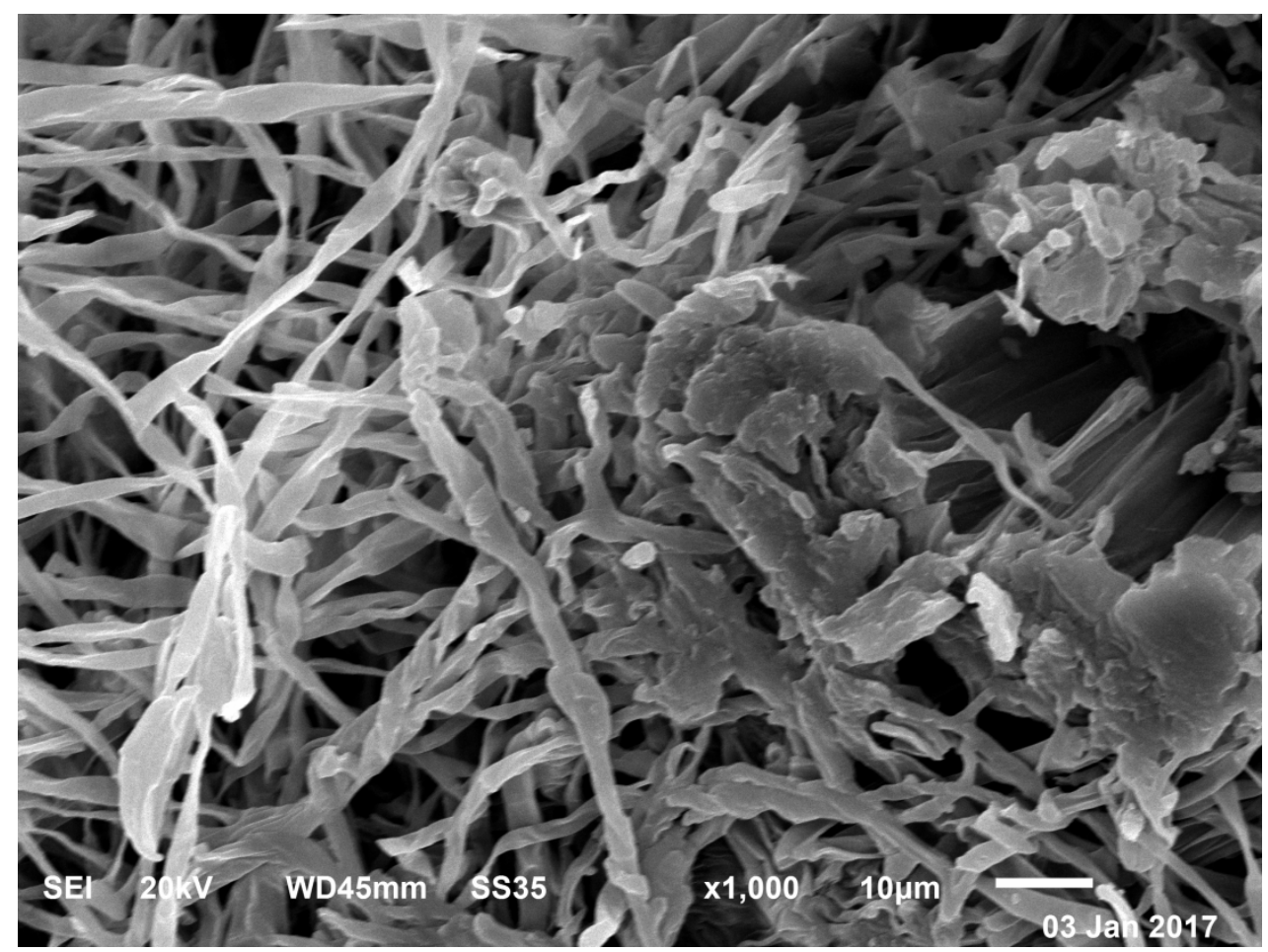

Fig. 2-e. Scanning electron photograph of pea seed surface used in laboratory diagnosis of Myrothecium sp. presenting colony and mycelium (1000X) 


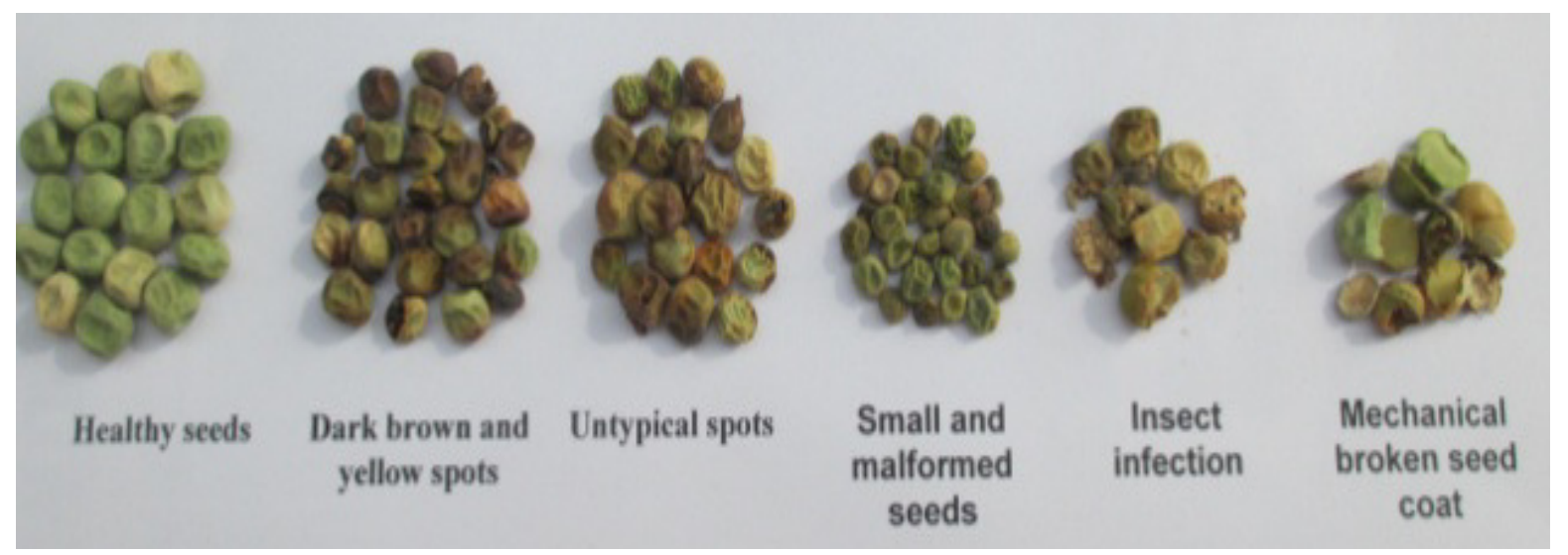

Fig. 3. Categories of discoloration pea seeds (6x)

Table 4. Percentage of seed borne fungi isolated from healthy and discolored seeds of pea Master-B cultivar using potato dextrose agar plate method

\begin{tabular}{|c|c|c|c|c|c|c|}
\hline \multirow[t]{2}{*}{ Isolated fungi } & \multicolumn{6}{|c|}{ Seeds color / (\%) of the isolated fungi } \\
\hline & $\begin{array}{c}\text { Healthy } \\
\text { seeds }\end{array}$ & $\begin{array}{l}\text { Dark brown } \\
\text { and yellow } \\
\text { spots }\end{array}$ & $\begin{array}{l}\text { Untypical } \\
\text { spots }\end{array}$ & $\begin{array}{c}\text { Small and } \\
\text { malformed } \\
\text { seeds }\end{array}$ & $\begin{array}{c}\text { Insect } \\
\text { infection }\end{array}$ & $\begin{array}{c}\text { Mechanical } \\
\text { broken } \\
\text { seed coat }\end{array}$ \\
\hline Acromoinum sp. & 0.00 & 0.75 & 1.25 & 3.00 & 2.00 & 1.50 \\
\hline Alternaria alternata & 5.00 & 8.00 & 15.00 & 3.50 & 7.50 & 4.50 \\
\hline Alternaria tenuis & 2.00 & 6.50 & 10.00 & 2.75 & 4.75 & 5.00 \\
\hline Aspergillu flavus & 3.00 & 0.75 & 1.25 & 0.00 & 7.00 & 5.50 \\
\hline Aspergillus niger & 0.00 & 1.50 & 0.75 & 0.00 & 2.50 & 2.75 \\
\hline Aspergillus fumigatus & 0.00 & 0.50 & 1.00 & 0.50 & 2.50 & 1.00 \\
\hline Botryodiplodia theobromae & 0.00 & 0.50 & 0.50 & 0.00 & 0.50 & 0.50 \\
\hline Botrytis cinerea & 0.00 & 1.50 & 1.25 & 0.75 & 1.00 & 0.00 \\
\hline Chaetomium globosum & 0.00 & 3.00 & 2.50 & 0.25 & 0.00 & 0.00 \\
\hline Cladosporium herbarum & 1.00 & 2.25 & 1.00 & 0.50 & 1.50 & 1.00 \\
\hline Epicoccum sp. & 0.00 & 2.25 & 1.75 & 0.00 & 1.25 & 1.25 \\
\hline Fusarium equiseti & 1.00 & 1.00 & 1.75 & 2.00 & 0.00 & 1.00 \\
\hline Fusarium moniliforme & 0.00 & 2.50 & 3.50 & 0.75 & 1.50 & 1.25 \\
\hline Fusarium oxysporum & 5.00 & 3.50 & 3.50 & 7.00 & 0.00 & 3.75 \\
\hline Fusarium poae & 1.00 & 0.50 & 0.75 & 0.75 & 0.00 & 0.00 \\
\hline Fusarium pogonea & 0.00 & 0.25 & 0.00 & 0.25 & 0.25 & 0.25 \\
\hline Fusarium solani & 1.25 & 1.25 & 1.00 & 3.00 & 0.50 & 0.50 \\
\hline Mucor hiemalis & 0.00 & 2.00 & 1.50 & 0.00 & 5.00 & 0.00 \\
\hline Myrothecium sp. & 0.00 & 0.50 & 0.25 & 0.00 & 0.50 & 0.25 \\
\hline Nigrospora sp. & 0.25 & 1.50 & 2.25 & 4.00 & 3.00 & 1.00 \\
\hline Penicillium sp. & 0.00 & 1.25 & 0.25 & 0.00 & 2.00 & 0.50 \\
\hline Rhizoctonia solani & 0.00 & 1.50 & 1.25 & 2.50 & 0.75 & 1.50 \\
\hline Rhizopus stolonifer & 0.00 & 1.25 & 1.00 & 1.00 & 2.50 & 2.25 \\
\hline Sclerotinia sclerotiorum & 0.00 & 5.50 & 5.25 & 2.50 & 5.00 & 5.00 \\
\hline Stemphylium botryosum & 0.00 & 1.00 & 0.75 & 0.00 & 1.50 & 0.00 \\
\hline Trichoderma harazinum & 0.75 & 2.00 & 0.00 & 0.00 & 0.00 & 0.00 \\
\hline Trichothecium sp. & 0.00 & 1.50 & 0.25 & 1.25 & 0.00 & 0.25 \\
\hline LSD at $0.05 \%$ & 0.07 & 0.22 & 0.59 & 0.29 & 0.14 & 0.44 \\
\hline
\end{tabular}


spots on the seeds. Alternaria tenuis produce untypical spots, while, Fusarium, Botrytis, Sclerotinia, Rhizoctonia fungi do not produce spots in pea seeds.

Results also showed that damaged seeds are more infected with saprophytic fungi than other seeds categories. These results are in agreement with finding of Kochler (1957). He observed that damaged seeds were much more susceptible to saprophytes and pathogens, than normal seeds during both storage and under field conditions.

\section{Effect of Discoloration on Seed Characters and Germination}

The results in Table 5 show losses in total protein, total phenols, weight of 1000 dry seeds and seed germination percentages in all discoloration seeds categories comparing with healthy seeds. On the contrary, moisture contents in healthy seeds record the lowest percent comparing with all seeds discoloration categories. Also, Fig. 4 show the effect of seed infection by pathogenic fungi in field and its effects on discoloration and morphology. These results are in agreement with Quenton et al. (2003) and Castillo et al. (2004). They explained that the biodeterioration of seeds due to many fungi which parasites on seeds during primordial, maturing and stored. Invasion of seeds can resulted in various damage including, reduce yields of seed, in both quantitatively and qualitatively, discolorations, decreases germinibility, mycotoxin production and total decay.

Table 5. Effect of infection and discolored pea seeds on some quality and component characteristics

\begin{tabular}{lccccc}
\hline Seeds color of Pea & $\begin{array}{c}\text { Total } \\
\text { protein } \\
(\%)\end{array}$ & $\begin{array}{c}\text { Total } \\
\text { phenols } \\
(\mathbf{m g} / \mathbf{g})\end{array}$ & $\begin{array}{c}\text { Weight of } \\
\mathbf{1 0 0 0} \text { dry } \\
\text { seeds } \\
(\mathbf{g})\end{array}$ & $\begin{array}{c}\text { Moisture } \\
\text { content } \\
(\boldsymbol{\%})\end{array}$ & $\begin{array}{c}\text { Seed } \\
\text { germination } \\
(\%)\end{array}$ \\
\hline Apparently health seeds & 33.20 & 1.50 & 335.8 & 13.8 & 100 \\
Dark brown and yellow spots & 25.25 & 0.71 & 310.4 & 14.5 & 60 \\
Seeds with untypical spots & 20.45 & 0.93 & 296.7 & 14.3 & 65 \\
Small and malformed seeds & 25.75 & 1.42 & 135.5 & 14.0 & 12 \\
Insect infection & 0.16 & 0.33 & 260.3 & 14.8 & 25 \\
Mechanical broken seed coat & 0.26 & 0.67 & 293.7 & 14.4 & 5 \\
LSD at $\mathbf{0 . 0 5}$ & 1.67 & 0.09 & 7.42 & 0.58 & 3.71 \\
\hline
\end{tabular}
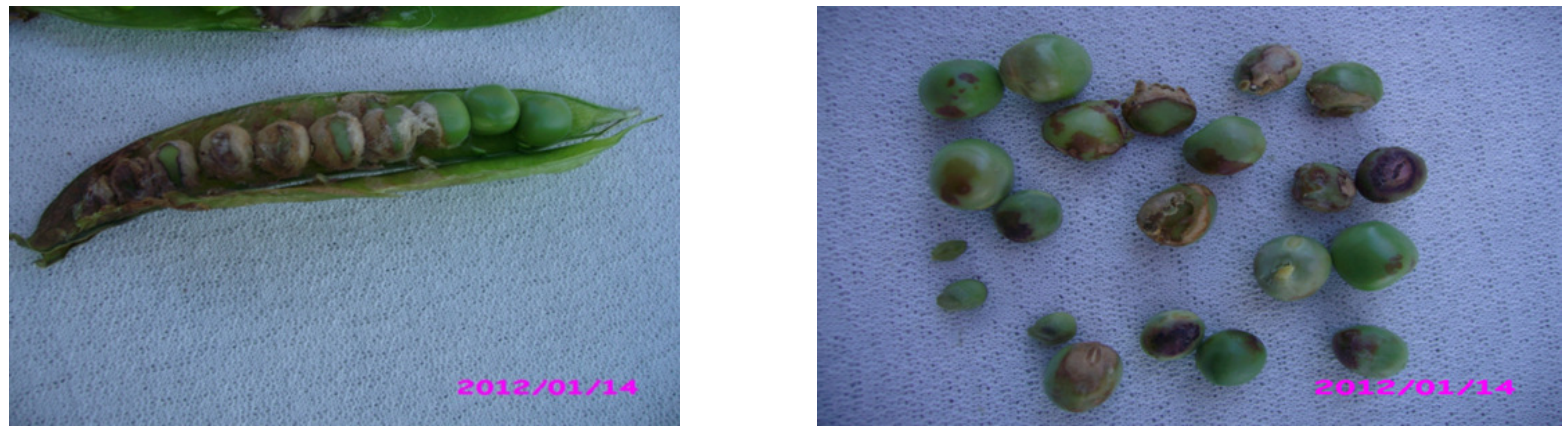

Fig. 4. Discolored pea seeds with different natural fungal infection collected from felids (6x) 


\section{REFERENCES}

Abdel-Al, A.M. (1994). Pathological studies on some seed borne fungi of Alfalfa in Egypt. M.Sc. Thesis, Fac. Agric., Al-Azhar Univ., Egypt.

Abdel-Hafez, S.I.I. (1984). Mycoflora of bean, broad bean, lentil, lupine and pea seeds in Saudi Arabia.Mycopathol., 88 (1): 45-49.

Agarwal, V.K., B.S. Mathur and P. Neergaard (1972). Some aspects of seed health testing with respect to seed borne fungi of rice, wheat,blackgram and soybean in India. Indian Phytopathol., 25 : 91-100.

Ali, M.S., J. Paterson and J. Crosby (1982). A standard technique for detecting seed-borne pathogens in peas, chemical control, and testing commercial seed in South Australia. Aust. J. Exp. Agric. and Anim. Husbandry, 22 (117): $348-352$.

Alves,C.M. and E.A. Pozza (2009). Scanning Electron Microscopy (SEM) applied to seed borne fungi examination. Microscopy Res. and Tech., 72 : 482-488.

Alves, E., G.C. Lucas, E.A. Pozza and M.C. Alves (2013). Scanning electron microscopy for fungal examination. Laboratory Protocols in Fungal Biology; Current Methods in Fungal Biology, Fungal Biology, DOI 10.1007/978-1-4614-2356-0_8@Springer

Science +Business Media,LLC.

AOAC (1980). Official Methods of Analysis. $13^{\text {th }}$ Ed. Association of Official Analytical Chemists, Washington, DC, USA.

Barnet, H.L. and B.B. Hunter (1972). Illustrated Genera of Imperfect Fungi, Burgen Publishing Co., Minnesota, 241.

Bateman, G.L. and H. Kwasna (1999). Effects of number of winter wheat crops grown successively on fungal communities on wheat roots. Appl. Soil Ecol., 13 : 271-282.

Begum, N., Z.K. Alvi, I.M. Haque, U.M. Raja and S. Chohan (2004). Evaluation of mycoflora associated with pea seeds and some control measures. Plant Pathol. J., 3 (1): $48-51$.
Booth, C. (1985). The genus Fusarium. Commonwealth Mycological Institute, Kew. Surrey, England, 237.

Burrges, L.W., M.C. Liddell and A.B. Summerell (1988). Laboratory Manual for Fusarium Research. Incorporating a Key and Descriptions of Common Species Found in Australia ( $2^{\text {nd }}$ Ed.). Fusarium Res. Laboratory Dept., Plant Pathol. and Agric. Entomol., Sydney Univ., 156.

Castillo, M.D., H.H.L. Gonzulez, E.J. Martinez, A.M. Pacin and S.L. Resnik (2004). Mycoflora and Potential for Mycotoxin Production of Freshly Harvested Black Bean from the Argentinean Main Production Area. Mycopathologia. Kluwer Academic Publishers Dorderecht, Netherlands, 158 : 107-112.

Czyzewska, S. (1983). The effect of pathogenic seed borne fungi on green pea (Pisum sativum L.) emergence. Acta Hort., 215 : 123-130.

Czyzewska, S. (1993). Survival of the pathogenic seed borne fungi in green pea seeds (Pisum sativum L.). Biuletyn Instytutu Hodowli I Aklimatyzacji Roslin Year, 188 : 289-299.

Dawar, S. (2005). Studies on the seed borne fungi associated with sunflower.Ph.D. Thesis, Bot. Dept., Karachi Univ., 213.

Dawar, S., M. Kulsoom and S. Rahim (2015). Seed borne fungi associated with coepea (Vigna unguiculata L.) Walp. Int. J. Biol. and Biotechnol., 12 (4): 565-569.

Dixon, R.A. and W.L. Sumner (2003). Legume natural products:Understanding and manipulating complex pathways for human and animal health . Plant Physiol., 131: 878-885.

El-Gantiry, S.M. (1985). Studies on fungal associated with soybean seeds in ARE. Ph.D. Thesis, Fac. Agric., Suez Canal Univ., Egypt.

El-Wakil, A.D., A.M. Mahdy and R.Z. ElMenshawy (2011). Scanning Electron Microscopically studay of sesame seeds infected with Macrophomina phaseolina. J. Agric. Sci. and Technol., (1): 96-99. 
Gill, L.S., J. Obi and S.W.H. Husani (1983). Mycoflora of some Nigerian leguminous seeds. Legume Res., 6 (1): 29-33.

Gilman, J.C. (1957). A Manual of Soil Fungi, the Iowa State College Press, USA, 450.

Godika, S., K. Agarwal and T. Singh (1999). Incidence of Rhizctonia bataticola in sunflower seeds grown in Rajasthan. J. Mycol. Pl. Path., 9 (2): 255-266.

Gomez, K.A. and A.A. Gomez (1984). Statistical Procedures for Agricultural Research $\left(2^{\text {nd }}\right.$ Ed.), John Wily and Sons, New York.

Igbasan, F.A., W. Guenter and A.B. Slominski (1997). Field Peas:chemical composition and energy and amino acid availabilities for poultry. Canadian J. Anim. Sci., 77:293-300.

ISTA (1993). International Seed Testing Association. International Rules for Seed Testing, Seed Sci. and Technol., 21: Supplement Rules.

ISTA (1999). International Rules for Seed Testing. Seed Sci.Technol. Suppl., 24:1-335.

ISTA (2008). International Rules for Seed Testing Edition 2102.ch-8303Bassersdorf, Switzerland.

Jatoi, S.A., M. Afzal, S. Nasim and R. Anwar (2001). Seed deterioration study in pea using accelerated ageing techniques. Pak. J. Biological Sci., 4 (12): 1482-1494.

Kandhare, S.A. (2014). Effect of common and dominant seed borne fungi on protein content of pulses.Bioscince Discovery, 6 (1): 14-17.

Khare, M.N., B.S. Mathur and P. Neergaard (1977). A seedling symptoms test for detection of Septoria nodorum in wheat seed. Seed Sci. and Technol., 5 : 613-617.

Kochler, B. (1957). Pericarp injuries in seed corn prevalence in dent corn and relation to seedling blight .Univ, Illinois, Agr, Exp. Sta, Bull., 617 : 74.

Kraft, J.M. (1991). Pea diseases. Aspects of Appl. Biol., 27 : 313 - 319.

Lewis, G., B. Schrirer, B. Mackinder and M. Lock (2005). Legumes of the world; Royl Botanical Gardens: Kew, UK, 577.
Machado, J.C. (2002). Concept and grouping fungi in relation to seed health testing-An overview. Seed borne fungi: A contribution to routine seed health analysis. Zurich: Int. SeedTesting Assoc., 9-18.

Marcinkowska, J. (1997). Micromycetes on Pisum sativum var arvense. Acta Mycologica, 32 (1): 31-39.

Michall, S.H., A.M. Abd El-Rehim, M.E. Abo Taleb and M.S. Metwally (1998). Effect of level of Ascochyta seed-borne infection on pea plants grown in cultivated and virgin soils. Seed Sci. and Technol., 26 (1): 125130.

Narayan, M.G. and K.D. Ayodhya (2013). Studay of seed borne fungi of different legumes. Trends in life Sci., 2 (1): 2319-5037 (Online) www.sciencejournal.in..

Nelson, P.E., A.T. Tousun and O.F.W. Marasn (1983). Fusarium spp. An Illustrated Manual for Identifiecation, The Pennsylvania University Press, Pennsylvania, USA, 218.

Nine, Y.L. (1986). Opportunities for research on diseases of pulse crops. Indian Phytopathol., 39 (3): 333-342.

Ozgonen, H. and G. Merve (2011). Determination of mycoflora of pea (Pisum sativum L.) seeds and the effects of Rhizobium leguminosearum on fungal pathogen of peas. Afri. J. Biotechnol., 10 (33): 6235-6240.

Pal, M. (1996). Pulse diseases scenario. Indian Phytopathol., 49 (2): 129-131.

Perveen Shahida and Abdul Ghaffar (1995). Seed borne mycoflora of tomato. Pak. J. Bot., 27: 201-208.

Quenton, K., A.S. Theresa, F.O. Walter, P.R. Johon, V.D.W. Liana and S.S. Gardon (2003). Mycoflora and fumonisin mycotoxins associated with cowpea (Vigna unguiculata L. walp) seeds. J. Agric. Food Chem., 51 : $2188-2192$.

Ramesh,V.B., S.V. Hiremath, M.K. Naik, Y.S. Amaresh, B.K. Lokesh and S.N. Vasudevan (2013). Study of seed mycoflora of soybean from north eastern Karnataka. Karnataka J. Agric. Sci., 26 (1) : 58 - 62. 
Rathod, R.L., M.D. Jadhav, S.K. Mane, S.M. Muley and P.S. Deshmukh (2012). Seed borne mycoflora of legume seeds. Int. J. Adv. Biotechnol. and Res., 3 (1): 530-532.

Saber, S.M., B.M. Aboul-Nasr and O.M.O. ElMaghraby (1998). Contamination of pea (Pisum sativum L.) seeds by fungi and mycotoxins. Afri. J. Mycol. and Biotechnol., 6 (3): 53-64.

Shaker, M., K.R. Momin and S. Hashmi (2010). Isolation and identification of some pulses mycoflora. Bionano Frontier, 3 (2) : 321-324.

Shakir, A.S. and H.J. Mirza (1994). Location of seed-borne fungi in chickpea seed. Pak. J. Phytopathol., 6 (2): 87-90.

Singh, B., J. Singh, A. Kaur and N. Singh (2017). Phenolic composition and antioxidant potential of grain legume. Food Res. Int., 101:1-16.

Singh, K., J.C. Frisvad, U. Thrance and B.S. Mathur (1991). An illustrated Manual on Identification of Some Seed Borne Aspergilli, Fusaria, Penicillia and their Mycotoxins. Danich Govern. Inst. Seed Pathol. Dev. Count., Hellerup, Copenhagen, Denmark.

Singh, P.N. and K. Gupta (1984). Seed borne fungi of Medicago sativa L., effect of culture filtrates of some isolates on seed germination and root-shoot growth. Seed Re., 12 (1): 132137.

Singleton, V.L., R. Orthofer and R.M. Lamuela-Raventos (1999). Analysis of total phenols and other oxidation substrates and antioxidants by means of folin-ciocalteau reagent. Methods in Enzymol., 29 (9): 152-178.

Solanke, R.B., S.S. Kore and S.M. Sudewad (1997). Detection of soybean seed borne pathogens and effect of fungicides. J. Agri. Univ., 22 (2):168-170.

Sonawane, V.V., B.S. Bharaswadkar and M.A. Chavan (2004). Studies on seed borne fungi of pea varieties cultivated in Marathwada. Flora and Fauna, 10 (2):131-134.

Tadja, A., M.B. Youcef, M. Rickauer, S.B. Bendahmane and M. Benkhelifa (2009). Characterization of Ascochyta as pathological species of pea (Pisum sativum L.) at the North-West of Algeria. J. Agron., 8 (3): 100-106.

Tariq, MS. ; M. Dawar Abid and SS. Shaukat (2005). Seed borne mycoflora of soybean. Int. J. Bio. and Biotech., 2 (3):711-713.

Venugopal, R.T., B. Rajeswari, K. Keshavulu and V.S. Varma (2015). Studies on seed borne fungi of soybean. Int. J. Agric. and Environ. Sci. (SSRG-IJAES), 2 (1): 16-24.

Wadje, SS. and MV. Baig (2006). Introduction to Plant Physiology, Biochem. and Biotechnol. Satyajit Prakashan, Nanded (MS) India.

Wilman, K. (2014). Pathogenic fungi in pea seeds. Arh. Hig. Rada. Toksikol, 65 : 329-338. 
دراســات على الفطـريات المصــاحبـة لبــذور البسلة وتأثيــرها على إنبـات البـــور وبعض صفاتهـا

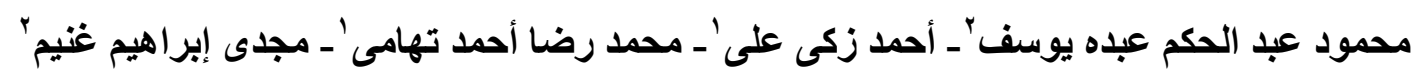

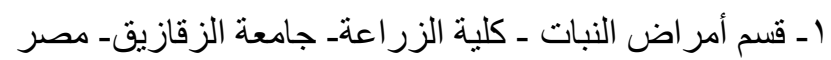

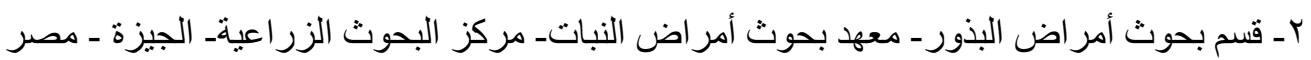

هدفت الدراسة إلى تحديد الفطريات الهصاحبة لبذور البسلة فى مصر وتأثير ها على حيوية البذور وصفاتها بأستخدام

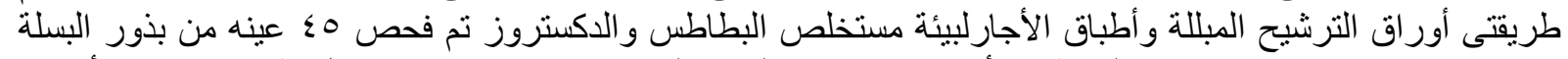

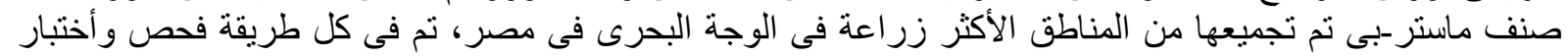
A...

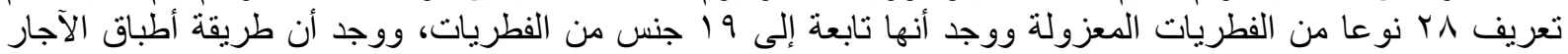

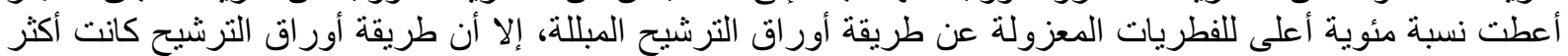

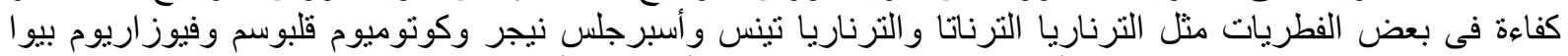

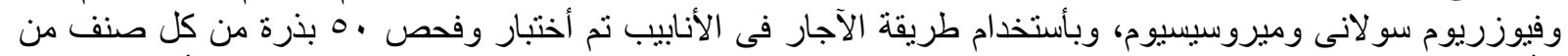

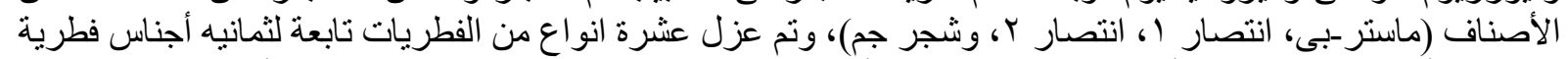

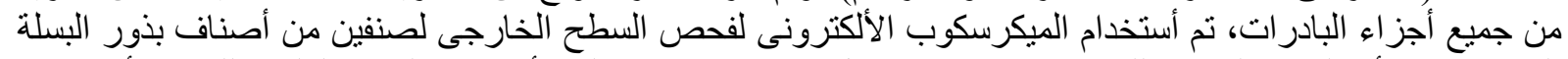

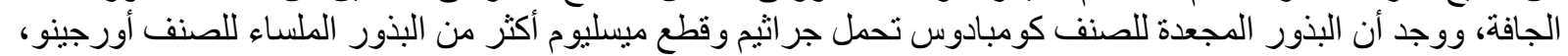

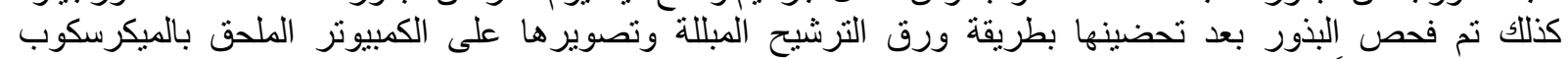

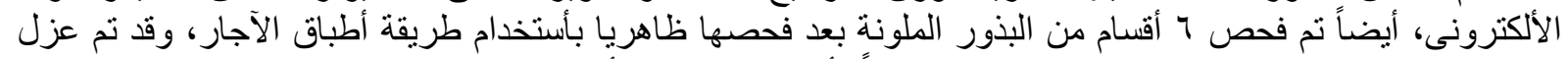

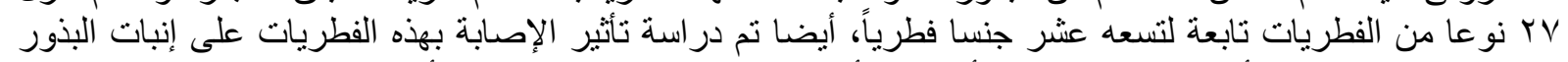

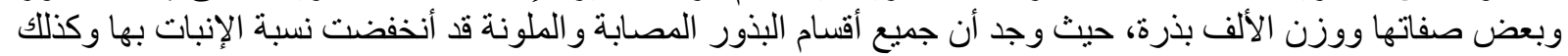
محتواها من البروتين و الفينو لات عن البذور السليمة، وعلى العكس من ذلك زادت نسبة الرطوبة الكبة بها عن البذور السليمة. 